\title{
On the Training of the Executive Branch of the Navy
}

\section{Captain Gerard H. Noel R.N.}

To cite this article: Captain Gerard H. Noel R.N. (1889) On the Training of the Executive Branch of the Navy, Royal United Services Institution. Journal, 33:149, 803-826, DOI: 10.1080/03071848909418084

To link to this article: http://dx.doi.org/10.1080/03071848909418084

曲 Published online: 11 Sep 2009.

Submit your article to this journal $₫$

Џll Article views: 2

Q View related articles $\square$ 
Friday, May 17, 1889.

Anmial of the Fleet the Ho. Sir henRY kEPPEL, G.C.B., Vice-Patron, in the Chair.

\title{
ON THE TRAINING OF THE EXECUTIVE BRANCH OF THE NAVY.
}

\author{
By Captain Gerard H. Noes, R.N.
}

1. Guneral Considerations.

THere is a natural feelini in the Navy that naral Ofticers should lave a roice in the decision of the types of ressels they may be somo day called upon to take into action, and there is so much controversy on this subject that the still graver question of tho training of Officers and men to man and fight these ships is allowed to fall into the background. The answer of an $\Lambda$ dimiral who had full confidence that thoso under his command were thoroughly trained to a sen lifo as men-of-war's-men wonld be: "Give us anj sort of ressels, so long as thes are seaworthy, and we will fight then," in fact tho training and efficiency of the personnel should be the naval Officers' first and principal care.

In September, 1855, four correttes were commissioned for tho Training Squadron, the purpose of which is to train young Officers and seimen in the practical duties of men-of-war's men at sea.. In former years similar squadrons of excrcise, under the less expressiro but more poetical title of "Flying Squadrons," hare been periodically organized and bept cruizing, not, perhaps, so much with a view to the training of jouvg senmen as to the employment of Officers and men in time of peace. The existence of these squadrous came to an end in the summer of 188:, and by many Officers it was regretfally supposed that the Nayg had scen the last of them. But the Boards of Admiralty under the present Gorernment, with wise foreknowledge of the absolute necessity for retaining in the seamen of the Fleet the attributes of a sailor, and that experience of sea-life, without which a man-of-war's man is of little practical ralue, determined to re-establish the squadron on a more effective s5stem; hence the formation of the present Training Squadron.

The advocates for the abolition of all that was formerly known as scamanship, who would sweep a way erery stitch of canvas, and erery spar that was not required for military purposes, were not pleased

roL. xIsIII. 3 G 
with what they considered the retrogrado step of re-introducing a system of training men as sailors; annd so confident were somo of them that seamarship was a thing of the past, that they were inclined to shut their ears to all arguments in opposition to their favonrite theories, and to consolo thenselres that such opposition must soon die a natural death. It is partly in the lope of awatening in these Officers $a$ senso of the real situation, and of conveying to whoerer may hear this paper a view of the other side of the question (for so often the condemnation of crerything that is not machinery is dinned into the cars of the public), that this paper is humbly sub. mitted for consideration.

Supposing, as it is here asserted, that the first caro of a naral Officer slould be the efficient training of the personncl of the Nary, let us consider how it is best carried into effect, and in doing this it is proposed to treat only of the Executive, and not to refer to the Civil departments, all of which, including that most important branch, the Fngincers and stokers, aro composed of specialists, only differing from their comrades in other employ through being sab. jeeted to a more rigorous discipline, and in most cases entrusted with greater responsibilities.

We hare to train the naral Executiro in such a manner as to make him in the highest degrec capable as a man-of-war's man; how is this to be done? First, let us imagino what his duties wonld be in time of war.

In a naral war our ships would be constantly at sea, probably only putting into harbour for repairs or coaling. They will be frequentlydnmaged through action with the enemy, collision, or grouuding; losing anchors, darits, boats, and spars, all of which should be, as far as possible, inmediately, though, perhaps, temporarily, replaced. They will frequently have to send away boats on various services, and, let us hope occasionally, parties as prizo crews. Coaling, often under great difficultics and with the greatest possible celerity, will be a constant necessits. They will occasionally fight in a general or an individual action; and sometimes (when there is no danger to the sbip itself) they will be required to land all available men for serrice ashore. 'Thes will often lave to take other ships in tow, or render them assistance. Away from naral ports the Executive will have to improvise methods of remoring disabled guns and replacing them with others, for the transport of heary boats, and for innumerable minor duties with regard to the supplies required for the Flect, all of which will hare to bo dono with tho utmust speed.

In order to accomplish these dnties effectively, the general ideas for the training of the lexecutire may be summed ap as follows:Officers and men sliould bo entered young (this has now been douc for many years); Officers and men should hare the maximum of sea experience; Officers should be constantly in charge of men, aud giving orders to them, and the men should know how to obey any order they receiro with alacrity; skill in handling men should be attained by the Officers, smartness and liandiness be attained by tho men; acute rigilance should be practised by both Officers and men, 
and the power of detecting the lenst sign of anything going wrong; accurate obserration, especially as to the appearance and movements of otlier ships, should be cultivated; an intelligent comprehension of what dangers are to be apprehended, and the best means of warding them off, is invaluable; a general readiness of resource, which can only be gained by experience, is most desirable; activity and fearlessness are indispensable. Thorough efficiency in boats, and on the part of tho Onicer's in the management of their slips, is cssential; and last, but not least, a thorough knowledgo of the use of arms, and for tlie Officers in addition, a proficiency in commanding batteries, or parties of men under arms, is of very great importance, training for which should commence from the carliest entry.

Having thus sketclied tho principal attributes which the Executivo should possess, it is proposed in this paper to point ont that without the uso of masted ships the requisite training is unattainable.

\section{Entry and Training.}

The present system of the entry of cadets and training of young Ofticers is satisfactory so loug as the youngsters are kept up to the mark in ser-going ships. The tendency to make too much of school. work at the expense of other more important matters is to be regretted. Bont work and close attention to the duties of the shipgiving the boys responsibilities from which they gain self-relianceand such training as will fit them crentanlly for the important daties of command, and those of executiro Officer, should nerer be disregarded; navigating and signal duties, \&c., should be closely attended to-in fact, the three ycars of a midshipman's service before passing for Licutenant should be more deroted to learning his duty as an Officer than to anything else. $\Lambda t$ present, by a wise provision, the last year or six months of this time is usually passed in the Training Squadron. Mlore elaborate instruction in steam, and actaal work in the engine-room and stoke-hold, have recently been ordered for young Ofticers; this, no doubt, will hare a beneficial effect, both in giving the Executive a better knowledge of machinery, and in rendering them more capablo of some day commanding vessels in which perhaps one-third of the crew will belong to the engine-room department; but it mast not be supposed that the Executires are 2equired to become Enginecrs, any more thau that the Engineers are required to become Executives; both hare their clearly defined and separate duties. Such is the amount of machinery now put into ships that it is increasingly necessary that the Executive should be trained to its use, and for the snme reason it is more than over important that mathernatics should be the most prominent part of a naral Officer's edncation. All senmanship is associated with tho working and utilizing of forces, and may be termed mathematical; it generates in the student the principles of applied mathematies, so that whaterer is the sonrce of power, a well-trained scaman soon adapts himself to its proper and most effective use.

Lieutenants when first promoted (especially those who earn early 3 G 2 
promotion by doing well at their examinations), are, after their long periods of instruction at Greenwich and Portsmoutb, usually very deficient in sea-going knowledge; the sooner this is rectificd by appointing them for service at sca the better, and it is not advisable to allow them to take up one of the special branches until they have shown themselres thoroughly capablo as Officers of the watcl. $O$ \& these special branches, such as gunner's, torpedo, and surveging, only a few words are needed. It is certainly necessary that a select few who show great aptitude for scientific pursuits shonld havo crery opportunity and cncouragement in becomine experts in their special line, so that they may eventually fit themselres for filling the positions of the highest authorities on theso matters. Apart from this staff of specialists, all other executive Officers should be more or less trained alike, their courses of gunnery and torpedo work should qualify them to perform the neccssary dutics on board a commissioned ship, and every Officer should be well acquainted with the duty of navigating, nlthough in this last branch the aptest should bo selected for the more important appointments.

No one doubts for a moment that it is desirable that our Service should produce men of highls scientific qualificntions in the gumers, torpedo, and surreying branches; but whatever may bo their other merits, the most valuable men in time of war will be those who can best command, handle, and fight their ships, in fact, the best seamen -tho aim of all training of the Executire shonld be to this end.

'The Captain who will best handle the ship of the present day, and fight her with success, will be ono who possesses tho maximum of scagoing experience, the power to command, and a clear-sighted understanding of his means of propulsion and his powers of offence and defence. Sea-going experience, and power of command, aro only gaincd by a life's study, the other items are mastered by carefully following the ever-changing systems of the day, being familiar with the nature and direction in which progress is likely to be made, so that when ouco in commission ho can readily understand tho peculiaritics of his ressel.

The entry of seamen as boys, and their first training in drill-ships and brigrs, is all that can be desired; from the drill-ships boss are now drafted to the 'lmining Squadron, in which they scrre until tho age of eighteen (when thes are rated ordinary senmen), and to which some return later on to serve another six months as ordinary seamen. This last period is not alwajs carricd out, partly because tho present 'Training Squadron cannot accommodate sufficient numbers, and partly in consequence of the men's services being required in other ships; but this training so far as it gocs is most beneficial. From the age of eighteen men engage to servo twelve jears; the smartest of them qualify for A.B. at about the age of nineteen, and the others with few exceptions before they are twenty-one. It would be a great lenefit to the Service if these threc jears (viz., from eighteen to twenty-ore) were passed in masted ships at sca, with this exception, that those who havo obtained the rating of A.B. under the three jears should be allowed to qualify in gunnery in one of tho home gannery 
sbips out of that time; but witil they havo had three years' man's time in masted ships-that is chiefly in the Training or Channel Squadrons-it would be well to consider them as yot cligible for howe ecrvice or mastless ships. Having acquired this amount of sea-going experience, they would jet have between eight and nine years to complete their first period of serrice, and from tho time of completing the first three years' sen-time, all (with the exception of those few required to fill the higher ratings in masted ships) would be available for manning the more modern types of ressels; the least intelligent as inan-of-war's men being emplojed in troop-ships.

The greater part of practical torpedo work is closely allied to a scaman's ordinary duty, and thero is no reason why the splicing and fitting of electric cables, the working of torpedo nets, and indeed everything except the handling of explosires, should not be introduced into tho carlier part of seamanship training. Gun, rifle, aud cutlass drills are all part of the training routine, nud as the Channel and Training Squadrons are composed of fully equipped war-ships, the necessary amount of these drills is carried out, so that even the joungest seaman is not strange to the weapons with which be may have to fight.

It has also been suggested that the crews of some of tho Channel ships should be occasionally turned over to the mastless battle-ships and cruizers, which are in readiness at the home ports, for a few weeks' training in the summer months.

After the period of sca-going training referred' to above, the seaman should be in all respects able-bodied; he is twenty-one years of age, and perhaps already a leading seaman, or eren a petts ollicer; now is the time to fit him for his duties in the battle-slip of the future, to practise him in such matters as the use of machinery in connection with his duties, the exercise of guns of vers heavy calibre, the working of torpedo-boats, and in fact all the more modern appliances of naval warfare, with which he may not before have been sequainted.

Since training for war service ruust nerer for a moment be relaxed, the seamen employed in mastless ships should be bept up to a state of proficicncs and smartness by constant buat-rork and whatercy may be devised in the way of grmnasties, besides the gunners and torpedo work and the ordinary duties of the ship; thes would be also -enuch benefited by occasionally having a few weeks' eruizing in the local sailing cruizers, if it could be conveniently arranged. Another rery important itew is the training in signalling duties, which should now be gradually incorporated with the other brancles of a seaman's trnining.

The gunners and torpedo instructions carricd on in sea-going ships cannot be too carefully attended to, and no cessation in the dril!s shonld be permitted nntil the crew of a newly-commissioned vessel is in erers way prepared to take their ship into action. Waste of ammunition in carrying out the quarterly practice is reprehensible; great care should bo taken to ohtain the utwost possible benefit from every round that is fired. The imperative necessity of getting a damaged gun or other wenpon again into action, without delay, shoald 
be impressed upon both Officers and men. The term "obsolete," which is so readily applicd to the matériel of tho Nary not immediately of the present date, has the demoralizing effect of rendering tho men dissatisfied with, and callous as to the cfticiency of any arms or gear that are not of the latest pattern. It should bo distinctly laid dorn that nothing is obsoleto which may be required for use in timo of var, and that it is greatly to tho discredit of all concerned if any part of the fighting plant, old or new, is allowed to get out of order through anj shade of carelessness or neglect.

The uso of mosts and sails is sometimes compared with that of a gymnasium, but those who think seriously on the subject must perceivo the difference, for in a gymnasium intellect is not particularly required, wherens in the smart handling of sails and spars it is indispensable, and indeel its absenco may endanger all concerned. In order to make a man-of-war's man, thero is no training compared with that of scamanship proper, as carried out in a masted man-of-war; it practises Officers and men in all the attributes which will be of the grcatest value in time of war, viz., intelligence, smartness, fearlessness, readiness of resource, and activity, and (with the Officers) in power of command. It is invariably the case that tho ablest and smartest seamen mako the best and most reliable gunners; not perhaps the best gannery instructors, for in them a quality rarely found in a good scaman is requisite, namels, tho power of committing to memory long pages of drill detail, and of snbordinating their own intellects to the subject-matter they haro to teach.

The working of war-ships under sail is tho nearest approach to what will be experienced in time of war. For instance, on board a ship in a squadron working into, or weighing from an anchorage under sail, every soul on board must bo on the alert, any neglect or wrong order given may cause at lenst great confusion, and perhaps serions accident, and all on boarl feel that unless the work is properly dono they will be the sufferers, probably haring to anchoi or to weigh anchor again, or make good some serious defect.

If it were possible to set the present types of modern fighting slips to the work they will experience in time of war, ramming the enemy, colliding, grounding, being damaged by shot and shell, their crews. replacing disabled guns, hoisting bonts in and out in dangerous weather, rigging jary rudders, taking disabled ships inl tow under difficult circumstances, \&c., wo could dispense with the training afforded by masts and sails, but as this is impracticable wo hare no other means of training onr Executive, in order to render them capable of coping with snch difficulties, than that of endeavouring to mako them seamen, and as such by battling with tho clements to derelop the readiness of resourco and self-confidence in critical moments which is indispensable to enable them to meet the emergencies and accidents of war. Sails are not in the question, except as a means to an cod, but an indispensable means, for which no other could be an effective substitute. Captain FitzGernld, in a paper on "Mrastless Ships of War," read at this Instituto in 1887 (sce Journal, rol.-xxxi, p. 121), baving condemned sail drill, \&c., could only suggest, in licu, 
that men " could bo giren so many hours a day to fiddlo with the live heads of Whitehead torpedoes with tho detonators in; or they conld bo set to work to hanumer sensitive fuzes into filled shell," but of course this is not meant seriously; nevertheless, what bas baffled Captain FitzGerald has baffled all others, for there is no substitute, and the only alternative is to allow the man-of-war seaman to become extinct. Imagine the Officer in command of a ship in war-time, who had no one on board he could depend upon to steer a course, to obtain sonndings, to man a boat under difficulties, to work tow-ropes, to rig a derrick, to improsise any purchase in lieu of some damaged machinery, to secure a torpedo boom broken adrift, or even to clear a flag foul aloft on the military mast; how he would bless the so-called reformers who had abolished sailors!

\section{Squadrons of Instruction, $\mathcal{S} \cdot$.}

In timo of war our flects will be composed of all arailable ships, many of which will be of the latest tJpes, powerful steamers without sail power, whoso crews will consist Jargely of stoker's and marines with a nucleus of senmen proper, and a full number of exccutivo Officers. In fighting the guus, in repairing damage, and in doing the innumerable duties (coaling, provisioning, boat-work, \&c.) upon which the fighting efficiency of the ship mostly depends, a Captain will haro to rely chicfly on tho ability and men-of-war's-man-like qualities of the Oficers and seamen under his command, and the Nars which can display the most of theso qualities will haro tho advantage. In times of peace the ships principally requircd for sea-scrvice aro those that can accommodate tho largest crews, and that in a healthy rnanner, providing for both Ofticers and men sufficient employment of such a nature that the Officers hare constant experience in commanding men, and in carrying out all kinds of intricate crolutions, and that the men have constant opportunities of nsing their intelleets and learning how to carry out orders with alacrity and precision. For this parposo masted ships with good accommodation should be emplojed where practicable, and kept cruizing as much as possiblo under sail.

Tho Arediterranean Squadron is necessarily composed of modern mastless ships (sails being of no ase on that station), which would with a few additions form a powerfal war flect; and on other important forcign stations there will shortly be a fair show of modern vessels. As these increase and tho older vessels aro withdrawn, the necessity of proriding for moro training accommodation for Officers and seamen will probably be met by increasing tho number of ships in the Training and Cliannel Squadrons. It would also be advantageous, if sailing training ships, such as the "Craiser," now at Malta, could be attached to our squadrons on other stations as woll as the Meditermaean; for instance, one miglit be stationed at Bermuda, and cruize in tho West Indies in the winter, another at Hong Kong, cruizing as far as Japan in tho summer, and perhaps a third in Austrnlia, all being employed in doing similar good scrvico 
to that performed by the "Cruiser," a ressel, for the bencfit of a fer weeks in:which, many a miclshipman has need to be thankfal.

It is often asserted that the Channel Squadron should foren the nucleus of our principal war flect in lome waters, and should therefore bo composed of tho latest types of war-vessels, which latter, it mast bo horne in mind, being mastless, carry very few seamen, aud as powerful steamers are not suitable for long periods at sea at slow speed (in perce-time), or much nse for training the seamen class eren if so employel, would it not he a better policy to make the Reserve ships the nneleus of our home flect, and to let the Channel Squadron consist-as at present-of tho older ships with plenty of accom. modation, and the neans of lecping their large crews in healthy cxercise?

Imngine the home flect consisting of the coastguard sbips, cach a battle-ship of modern type, having attached to her a vessel of "M[ersey" or "Mrelpomene" class, another of "Rattlesnake" class, and two torpedo-boats, manned when at her coast station by a reduced crew. of trained seamen, marines, stokers, \&c., and able at twenls-four hours' notice to complete her crew, and those of iner satellites from the constguard men of lier distriet, and be on lier way to the rendezrous at aus port in the Channel. Here you would have a splendid and fully equipped fleet, manned in a most etlicient manner, and ready for service; so orgauized that when not called out, the crews of the ships in their reduced state would be sufficient to keep crerything in perfect order.

Again, imngine a Channel flect of six or perbaps eight such ships, as "Minotaur," "Hercules," and "I'riumph," intended to carry ou the training of the jounger Ofticers and scamen, principally with the view of accustoming them to a sea-life. Periodically these ships might be brought to the home ports, and turned orer to modern figliting ships, each of their large crews being divided so as to man two or more of these ressels for a few wecks' cruize in the summer.

The Training Squadron is at present doing admirnble work, although it can hardly accommodate a sufficiently large number of men to achieve tho desired amuunt of training. 'Jhe ships of which it is composed are the best of the older cruizers, and as they are fairly good steamers and well arned, there is no fenr for their safety should at naval war be suddenly forced upon us. They are well masted enough to enable then to make a good passage under sail, and their accommodation is satisfactory, the four ships carry about $1,400 \mathrm{mcu}$ all told, of which about half are ordinary seamen and hoys under training. The work devolving on the Commnnder or First Lientennnts of these ships, augmented as it is bJ the frequent changes of Officel's and men. and the constant training daties, in addition to usual routine work, is very arduons, and these Otficers deservo every encouragement. The petty officers have also.much more work than in most ships, owing to the youth and inexperience of those under their charge, who require continual instructire supervision. 'The work of thie other Officers is nothing out of the common, bejond the fact of these ships having about double as much sea-work as any others. 
Besides the instruction in seamanship which is in conslant progress, the ships of the 'I'raining Squadron are exercised in waral tactics either under sail, or when stcam is raised, under steam; the new signal books have been thoroughly studied, and it may truly be said that more signals aro made in this squadron than in any other.

During the first three years in one of these ships, the "Rover," 482 ordiuary scamen nud 362 boys had an average of six months' training; 44 midlshipmen served on board the ship, of whom 30 passed for Lieutenant in seamanship) (10 ohtaincd 1st class certiticates, 12 Wnd class, and $8 \mathrm{3rd}$ class, two midshipmen being turned back). During this period the squadron accomplished. the distance of 55,432 miles in 11,070 hours, of which 32,210 miles and 7,463 hours nere under sail. Eighlty ports were visited, the squadron arriving or leaving under sail alone 53 times, occasionally under diflicult circumstances. As a specimen of the sailing qualities of the squadron, on one occasion the passage under sail from Tencriffe to Barbados, a distance of 2,580 miles, was made in $16 \frac{1}{2}$ days, au arerage of 156 miles $\&$ day; on another occasion the scuadron areraged under sail 200 miles a day for 9 consecutive days, completing a passago home from Bermuda in 19 dnys.

The cruizing of the Training Squadron in the West Indies in the winter, and in the. Mediterrancan, Baltic, and home waters in the summer (during which the squadron twice took part in the fleet manoenvres), was a raried experience of work, interest, and pleasure ; many interesting foreign ports were risited, where the Officers had the opportunity of seeing the ships and dockyards of other navies, and were everywhere received with the utmost cordiality and good fecling; in fact, augthing nore instructive and generally bencticial to both Officers and men than service in the 'l'mining Squadron cannot well be imagined. There is reason to hope that the squadron maysome day be increased in number, or what will be even better, that a second squadron similar to the present ene may be fitted out.

\section{Conclusion.}

The opiuions expressed in this paper as to the importance of seamanship training are thought by some people to be old-fashioned and inapplicable to the present das. : 'l'lat. these or similar opinions were held by our forefathers there is no doubt, and it was through the strict adherence to them that former great naral commanders earned the name of being the best scamen in the world, ard as such, carried all before them, making our country what it is now. Are we to lightly barter arras the heirloom of their prestige? Is thero any reason why England should not still boast of at least giving her naral Officers the opportunity of being tho must experienced scamen in the world?. If to be experienced seamen is out of date, we may find to our cost that winning a raral action is also a thing of the past.

It is believed to be a fact that none of the principal ocean stcanship companies will admit an Officer into their emploj, unless he has 
served an apprenticeship of fonr jears in square-rigged sailing shipe, and some companies go even further, and will only take an Ofticer who has commanded a sailing ressel. What the shipowners find is that a youngster apprenticed in a steamship learns how to clean bright work, but practically little else.

"The reasons for the unpopularity of scamanship proper are not far to scek : in the case of some Officers-wo hope but few-the real fact is that they do not like rork, and in masted ships on long cruizes they are not so comfortable as in mastless ships constantly at anchor or alongside the dockyard wall. The voices of theso gentlemen are frequently heard in the Servico papers, deluding the public into the belief that theirs is the adranced view of naral matters. Another class of objectors to seamanship training is found in certain Officers of the scientific branches, who deroto themsclves so entirely to their own particular work (often to the great benefit of tho Service), that they lose sight of, or eren ignore the necessity of employing means for the purpose of training which are foreign to their sympathies, forgetting that hitherto we have only emplojed Officers and men who have been bronght up as seamin, and that we hare no experience of what is to be expected/if their training as such, ceases. It is notorious that no other means of training is suggested by theso Officers bejond a vagne assertion that the personnel ought to be trained in the ressels which they will hare to figlt, which apparently implics maintaining our Flect on a war footing. Again, a third class of opposers to seamanship training is composed of those who, on political gronnds, would insist on the pushing forward of modern ships, and -disregarding training-are satisfied with tho personnel so long as it is numerically sufficient, fecling (and perhaps with reason) that while the older slips are employed, and men-of-war's men are trained as sailors, there will be so much less moncy to be spent on the newer vessels of the war fleet. This party includes in its numbers somo of those Offeers who liave completed their term of serrice, or who, for other reasons, have no farther prospect of commanding our ships or flects, they therefore are apt to drop out of their reckoning the im. portance to a Captain of having with him experienced Officers and seamen on whom to rely in time of war. The cause of objection of this class descrres attention, its remeds, howerer, is not found in sacrificing ono great object to attain another, but rather in so providing for the wants of tho Nary that neither tho personnel nor tho matériel should suffer; and by a judicious organization the war flect be periodically mobilized, while the time during which it is not mobilized should be passed by at least the younger Officers and seamen in healthy and beneficial employment at sea.

Thero is undoubtelly in ncarly all esperienced naval Officers a latent, if not an actire opinion, that seamanship in tho sense saggested in this paper is still necessary, latent and unexpressed by some because they aro fearful of being classed as out of date; but is tho withholding of such opinions beneficial to our Serrice? It is to bo hoped that those who honour this papcr by joining in the discussion will throw off all reserve; and if some speakers do not possess eren a 
latent regard for seamanship, they will not express their objections in rague terns, but rill suggest some definite alternative either for the training of the Exccutive or for its reorganization.

Lieutenant IIExhy Craxbercars, R.N;: Mr. Chairman and gentlemen, the mubject of neral education appears to me to bo esentially one in which Ofioer below the ago of fifty certainly should mainly interest themeelrce, becaneo if they now are in aclire serrice as Cuptaino or Commenders, in a rery few rears' time the feots afficered by young officers will be entrusted to their care, and if thoso Ollicers wot oufliciently trained, thes (the Admirals) rill suffer probably like Admiral Bing suffered in the last centurs, and on their shouldcrs will fall the terrible wcight of inefifiency which is not duo to them, but to the fact that the subject of naral education is looked upon at preeent as of sccondary importance. It is really of primary importance. We hare at last discorcred that wo hare not enough ships, and aro going to build serenty more, but we have not got suflicient oflicers to begin with. Supposing, howerer, for the agke of argurnent, that wo had then, let us look at the suggestions that are brought formard in this paper. Tho first thing which atrikes one is that we had better get our definitions. What do mo mean by "scamanehip "? Wo talk of "Eailors," scamanship," and "geamen." One man means ope thing and another man another thing. In my private opinion "sailors" are csentially men who hare passed awas. There aro no "sailors" in the strict senoe of the torm, any mors on the actire list, or hardly any. Without disrespect, if I nias asy wa thero are hardly ans "sailors" of the olden iass left; but I should be extremely sorrs to say that there are not rery good "scamen." "ilies aro rery dietinct people from " sailors :" as distinct as chalk from checse. "Sailors" no longer cxist, but emamen may exist to the end of days. As long as the sea exists, so long scamen will axist. There will be always machines to put on the sen, which you call "ships," which people will be ablo to manago in all winds and weather; to run them into one mother if they are enemies, and to keep clear of each otber if they are friends. These men are scawen. We aro mither apt to be down on our luck on this question, and to think that scamen are passing uray. They hare not, and thes need nerer pass away. The joung men of the present day have as good intelligence as their fathers, or eren their grandfathers, and you have as good material now as erer jou had before in the Serrice. That is a statement made by Admiral Sir Geofirey Hornbs, who, I suppose, is one of the best Oficers in the whole Nary, and he ays, "You hare as good material now as erer you had;" but he adds as 3 rider to his etatement, " Tou hare splendid material, and jou make absolutely no use of it." Fou hare intelligent joung inen, you adwit them st fourteen, but jou do not train them. Talking about this question of traiuing, it is a rery good plan to begin at the beginning. Captain Noel, of course, is dealing with a vers largo subject, but I wish to ask this question-Ind wo not better begin at the beginning, and train our young Officers from the day of their entry? Scarely a single reference has been made to the incfliciency of the present system of training, and the possible eflicienes of a modified system. As a matter of fact, it is impossible to attain the objects lnid down in this paper unless you make a radical change in tho wholo system of train. ing, beginning at the age of fourtecn. Captain Noel says, "The threo ycars of a midshipman's ecrrice before passing for Licutenant should be more deroted to learning his duty as an Oficer than to anything elsc." Quito so. Ercrybody rightly said "IIear, hear" to that statement, but how are me to do it?. I know an Officer, present in this room, who has a son in the Rosal Nary. The boy is on the East Const of Africa, where all day long ho is amay picking up raluable cxperience in open bouts, copplosed possibly against slare dhors. Wilh ten or twelre inen, you como suddenly on a slare dhow, and on such an occasion tho intelligence, the pluck, tho decision, the forcthought, evergth an which makes a joung scamsn, would hare to be brought into play at a moment's notice. What is happening to that boy? Firery woek that passes orer his head is so nuch time lost. Why? Becaue, under the present system, ho is not under a Naral Instructor but is uray in a boat. The actual fact of the matter is that these midshipmen on the 
East Coast of Africa are going to be recalled and put into thesso large slipe. Thes are going to be remored from the sphere of experience to be put into tho sphere of theory, because if thes are not taken awaj they mas only obtain thind clasecs at Grecnirich, and jour best Offiecrs will be delajed in promotion, whilo your least good Officers will bo promoted rapidly. Now the father of this young boy is an extremely able Officer, who belongs to the old school, but he also has gone with the times, so loc is saring this: "I know that from a seaman's point of view it is bad that my boy should leare his present ship, but I know from the man of the world's point of riew it is a good thing that he should lenve that ship. Which am I to do, to ruin his carcer, or to make him "no sailor'?" Which would you do? Which woild any father in the room do? Ife would chuck the scamanship orer. board, because he does not want to ruin the bor'scarcer-ard there is the cril of the whole system. You hare a srstem at present which morks cxtuemely badly; and which erery jear works a littlo rorse, nhich not only is condemned by outsiders, who ece the most of the game, but is also condemned by the intelligent Sub-Lieu. tennnts themsclres. I hare spoken to them, and suid, "I'utting all prejudice on one side-for we are all old Nary and are all new Nars-rrbat do you think you know about seamanship? What hare you had the opportunity of learning?" "This man whom I was spcaking to, a rery intelligent "Sub," said, "To tell sou the honest trutl, I do not know much, and for a very good reason, that I hare nerer been taught." But whose fault is that? It is the fault of the system. If he is taught it (i.e., sconanship) his career is jammed, becauso he gets a third class at Greenwich, and if he is not taught it, he is perlisps put, at tho age of twenty. one, on board a elip, an ironelad, which has cost half a million, without haring had any expericaec. In the old days, in the dars of our gallant Chairman, a lad at the age of serenteen knew more scamanship than our Lieutenants of four years' standing. I gay with all confidence that that is a grear scanclal, and we nuat alter our system. Fou referred, Sir, to a damaged gun, and you said that now. a-dars a scaman could not replace a damaged gun. I think it is only fair to the acamian of to-das to say this : if Lord Dundonald was sitting there he could replace his gun, becsuse trio felloms could lift it, and eren forty years ago the guns were mere tors compared to what they are now. If a gun gets damaged now, the best eseansan in the world cannot lift it with the appliances on bárd ship, not the rery heary guns, therefore how could they be remored and replaced? What purchase could you get to lift your rery heary gans on bourd ans ships? Eren if you lisd masts you could not trust to masts. It is not a question of ecamanship, thercfore, but a question of dead neight and " purchase." The size and porrer of tho ruan has remained the same, but the weight of the gun has increased iu an alarming proportion, so that I do not think it is fair to the scamen of the present day to say that they could not replace their guns. The lecturer refers to seamanship in this way: "Imaginc an Oficer in command of a ehip in war-time who had no one on board he could depend upon to steer a course"-a "course" is stecred by compsss; and masts, yards, and sails are perfectly unnecessary in order to impary such knowledge to our men--" to obtain soundings" - this is done by using a lead-line, and no masts ure required in order to instruct a man in the art of taking somndings - " to man a boat under difficulties"-no masts required in orler to do this-" to work tow ropes"-Jou can tow a derelict without masts-" to rig a derrirk"-a derrick requires no masts beyond one, which mould tale the topping-lift; I beliere I am right there-" to improrise any purebase in lieu of some damaged machinery"purchnse can be inproriscd without absolute masts; purchascs are milde with ropes and blocks; if jou will go to Woolwich jou will sec some marrellous purchases for lifting thesc 63-ton guns- " to secure a torpedo boom broken adrift" - that requirs no mast, or certainly not more than one military mast - "or eren to clear a flag foul aloft on the military mast "- mell, that requires a man, as we all agree, who has had training, and for that you require more gymnastics. As regrards training squadrons, the training squadron is an absolute necessity for maintaining our supremacy ut sea as a fighting Power, not on account of the sails, but on account of the seicntife iutelligence, the originating porer, the general activity and bodils health acquired bj trained men. I think that these training squadrons are most useful for that. I lope that they will continue so. 
Admiral Sir Georae Wilces, K.C.B.: Last jear'I met Cuptain Shaw, of tho Fire Brigade, when lie informed we that he had ceased to tale men-of-war's nicn into his Fire Brigade, because they Lad lost their character of agility. That being the casc, rou may inagine with what pleasure I hare hesrd Cuptain Foel's addrese. I agree with him in nearly crers point. The Training Squadron has been of immense utility; the First Niaral Irord descres great credie for laring had the woral wurnge to re-cstablish it. There is no doubt a large number of my brother Oflecers (I asj it with regret) who ridicule the ides of a ship with masts, and spars, and (1.ls. under any circumstances, but I maintain they are krong, and if we want to keep up the cliaracter of the British sailor we must retain nasts, and spars, and asilb, but for training only. Of course, with an increased Narf, instcad of four apips there must be at leust sir, but that is a detail. Captsin Foel has carried us up to the point of the men quitting the Training Squadron; I rather regret that he bes not gone further, because there is no manner of doubl that any great measure of suecess in our battles of the future will be due to the most skilled gunners. I heve had the opportunity of watching what has been going on in the training of our men, and I reully think it is most fuulty. When the "Ficellent" system was frot establisbed we liad not a standing Nars, and it was arranged that a suflicient number of men should bo traiued, so as to get a captain for crers gun, and crough wen to work tho magazines; but in 1852 we established a standing Nary, when we ought to have amended the whole sjstem. Many of jou would hardly believe it posibible, but our men are still dirided into slecp and gonts, and any young max who has been a bit of a scamp, and sonio of us, I hare no doubt, have bcen scanps in our time, is sent to sea before he has become a skilled gunner. What is the coneequence? The number of young men whom I had to get discharged from tho Fiary during my period of serrice at Portsmouth really pained me, ind chiefly for breaking leare. Whercas these joung men, these scamps, would be just the men wo should be glad to haro in battle. They are trained at great expense aud then discharged; whereas, if the shecp and the goats were all mired together, the latter would forget all their troubles, and most likely turn orcr a new lenf. JIanj of them mould narry and settle down. There is another point Captain Noel has onitted, another very important question-slokers. Nothing can be worse than the training of our stokers. I was not out with the ships last jear, but I read in the newspapers, and I read that most raluable report of my threo brother Officers, which stated that there was a great want of trained stolers in tho Nary. Now you cannot train a stoler under tro or three jears, and jou cannot train them witliout driring your ships at full speed. I do think it is neccssary that we should follow-I am not too proud to follow-the Italian Nary, and adopt their plan, and becp one or tro ships constantly sunning out to Malta and Gibraltar at full spced. What is the use of tolking about a ship being able to steam $18 \mathrm{knots}$, when you hare not got tho stolers to drive her at that epecd? It is absurd. With regard to the Oficers, I would make one suggestion: there is no doubt that the young Oficers of the present day are a splendid set of young men; but I think they want a little more, I might say a good deal more, sea-training. I hare alwass thought that when they quit the "Britannin" the nisral jnstructors might bo left behind, and that for the three or four jeurs thes are away the boys might learn scamanship; going away in their boats teaches them something better than working in the fore cabin. But it is aid, "Ol, but if you interrunt their studics they will not get firc first elasses. Keally, I do not much care about it; I am thinking of the $\boldsymbol{N}_{\mathrm{n}} \mathrm{y}$ of the future; I want to haro fighting men and foghting Officers, and that cannot be learned by studying $x .^{l}$. A gallant friend of mine, who, I am sorry to see, has left the room, and therefore perlaps I ought not to quote hirn, said, rers truls, many jears ago when he was pressed, that the success of an encounter depends a good deal more on

It is, of course, neccssary to lare a proportion of Oficers with high scicntifio attainments. After the examination for the rank of Lieutenant (which should not occups more (lian a few months), joung Officers who have a talent for mathenatics should be allowed to study at Greenwich. A great deal of time is now wasted in cramming those to whom it is distasteful. 
the stomach of tho Captain than on anything elsc, aud he nerer said a truci woid. Well, but stomach can only bo acquired by experience; it is impossiblo rithout ses training. You would scarcely beliere it possible, after what our gallant lecturop hes said, that a Conmander was lately appointed to command a ship who had not been to sca for ten jears. Well, no insurance offec would insure a merchant ship under such circumstances. Gentlemen, I won't detsin jou longer. Unfortunate circumstances lare presented me from attending any public mecting during the last fire or sir months, but I should like to cxpress my gratcful thanks to those gallant brother Oflicers of mine who have agitated and brought about such a grend increase of the Nars. I am sure you will all join with mo in expressing our thanks to them. Thero is no doubt of this, that without a powerful Ninry England will be lost. There must not be a question of an cnceny landing on our shores : thes muat not be allowed to land! I see a gallant General here, who will forgive me for saying that if the eneny does land, corps d'armées will be of no use; it must be: question of the command of the Channcl.

Captain The Right Honourable Lord Craries Beresrord, C.B., MI.P.: I think the thanks of the whole Serrice ought to bo given to Captain Noel for this paper. It is impossiblo to couccire anjthing of greater importanco than the training of Oflicers and men for the sea. Captain Noel, I think, has been a littlo hard on somo fer of us who hare opposed as hard as erce we could haring masts, Jards, and sails in battlc-ships; but I think he has misunderstood our reasons for that opposition, and I will cndcarour to explain what our reasons are. We hold that we hare a Flect insufficicnt for our wants, and therefore erery ship we hare, of ererj sort and class, ought to be a fighting ship-in other mords, it ought to be ready at a moment's notice for actiro service. We hold that if you put masts and jardis into a battle-ship proper, Jou maj put her in a position (bj haring these masts and jards when suddenly called into action) of losing the action becauso she las got them, from the mere fact that in these days of aceuracy of artillery it might be possible to boock thoso masts and sards orer and foul tho screx. On the other hand, I hold as strongly as Captain Nocl, and I heartily agree with him, that the firet necessarics in Jour ships are scamen, that is to say, men of actual experience at $\mathrm{sca}$, and a man cannot be an eflicient $O$ ficer or a proper man to man our ohips unless ho has actual experience, and experienco of a rery extended charactor, at sea. I cannot speak about mysclf at this moment, but I fecl rery often in the House of Commons (as I sometimcs cnlcarour to utter thouglats through my mouth that I beliere are the thoughts of $\mathrm{my}$. brother Officers) that it is impossible for me to do 80, as I hare not been at sea for the lagt six or ecren years; and many Sub-Lieutenants in the Serrice would giro mo tro stone and a beating with torpedoboats, is their practice is superior to minc. I entirels anrec with Captain Foel as to the necessity of actual experience ut sea. I do not wislu to criticize him ecrerely, but I do not think he has explained what wo ought to do. MIs own opinion is this, that taking the home llect, the home flect ought to be sent to sea working in all sorts of weathers, threc or four montbs in the ycar actually at sca. I would use tho "Admiral " class as the Channel Fleet, but I would take some of thicir coal out and put a 5-inch steel belt on them to keep out high explosires, and so make them good fghting ships, for at present with their light end, which can be so casily pierced, ther are liable to go orcr. Then I would hare not a half-and-half machine, like tho "Minotaur," where men are doing more or less uscless work, in ing opinion, but liare a regular training equadron in the Clinnel, besides a regular training squedron to go round the world, as it is doing now. I would bare tro training squadrons, and besides that I rould hare a cruizcr in crery station that England posacses. There is a practical way of doing it, but I do not think sou get what you want if jou mix up the two things. You must begin by sending your men into the cruizer suips and teaching them what is essential in order to obtain readiness of action and rcsources, without which no ecaman is worth a snap of the fingers. 'The essential tling, ab tho gallant Admiral has pointed out, is practice with artillery, that one shot may win an action. You must tcach your men to bo as capable of pitching a shot in the proper place as it is possible to do. I entircly sympathizo with the gallunt Admiral. For years he hos been trying to get a regular eca-going gunecry school, but besides that we must teach our men to be seamen. Thero is another ques. 
tion about tesching the exceutirc branch more about the use of machiners. In the old dass, eren in my time, I know perfoctly well that your executire could tell jour artificers how to repair a forotopsail jard if it was sprung. It is just the same now; sour crecutire ought to be able to eas to the Chief Enginecr, "Do so and so." It is tho Clicf Engineer's work, but he muet be uoder the erecutirc, or else you will neres win your action. Whether you are right or wrong, tho erceutiro should say, "I want that shaft repaired that way." The Captain of tho ship and tho crccutirc Officer, in my orn humblo opinion, should know crers bit as much about the ship as he did in the old sailing days, and as how a thing is to be done, no matter who is the expert to do it. The lecturer ulso spolo about tho question of signalling. In my opinion it is a most inportant queation to teach Officers and men far more of ignalling than thes knon at present. At a particular moment in an action a clerer Adwiral mas sec something that would let him win tho action. What doc3 he want to do? IIe wants to get that something out of his lead into his Captain's, but under jour present system he cannot do it. I know the Allmiralty hare tried to improro it, but eignalling is bad all orer the world. Our present system of signalling not only in itself is bad, but the men that ne cmploy are not suflicient. We must also remember that a whole fleet may bo disorganized in a moment because your signalling staff has been destrojed. It therefore seems to we that the question of signalling should be largely added to the edueation of Oficers and men of the Fleet. With regard to trained stokers, the stoker 3 are the men who really win jour aclion. We may say what we like of the man in the engine-room, but that man has to be a great deal moro plucly than any of us : he nerer bnows when a torpedo is coming wowerds the ship; he has to run the slip, and ho docs not know whero he may bo the next moment. That man has got to rork at those fires in a rery hot place, but unless he gocs on working, the Cuptain cannot put the ship in position to ensble him to win his action. Therefore I think the truining of jour stokers and engincer Officers ought to be entircly remodelled and reorganized. We haro al present an entirely. haphazard system, which would be rery detriment al to us if we went to war. I aloo entirels agree witl what tle Admirul said as to the question of seamps. I was rather s scamp injself, I am afraid; but depend upon it a great number of men of this kind, as the Adniral has cxplained, who hare been sent out of the Serrice are tho rery. men you want to fight. Why the Admiralty want to get rid of these men for some offence againat discipline I rcally do not hnow. Somo peoplo are always cantankerous. As a rule, the best boy in the sehool is the biggest "pickle" he has the pluck to get into, and the ecamps aro rery often the best men jou hare got. They are altogetler different from the scouudrel and the blockguard. $A$ scamp is a good chap, alirass was, alwajs ready for a fight. But many of these men are debarred by somo absurd organization that they did not know of, thes aro debarred from hecoming seamen-gunners. In my opinion Jour Gunners Establishment is too cxclusire : you should train all the ecamen and all the Oficers, as far as you can, to gunnery. It is not that wo do not rant cxperts in the Gunners lepnrtment, but the Olicers and inca should haro the adrantage of becoming gunners, in $\mathrm{my}$ humble opinion. I also agree with what the Ddmiral said about tho jounger Officers of the das. I beliere we nerer had a persounel better than we have now, both of Officers and men, and I an not going to make'msself out an old man, I hope. But as to tho jounger men in the Serrice, I think the whole of their wish is that they should bo taught in peace what they would have to do in time of war. We must make our men and Oacers able to do by ordinary experienco whint they would hare to do in time of war. I think their nind is at one on theso ques. tions which I bare so often endearoured to bring before the public; and on which I think my brother Oficers agree witlı me-if I did not think they would anree with me I rould not sas it-but we want organization. Our want of forethought in many questions connected with the Flect is perfectly extraordinary; and I do belierc, thougl perlıps some of my geniors won't agrec with me, that you will not get that altered until you alter the present systen of the Board of Admiralty, so that there shall be a responsible head for cach detail, which you can hang up when anthing goes wrong. "If ansthing goes wrong at present, all they say is "Oh, it is the Board of Admiralty." I do think, in conclusion, that Captain Nocl descres the thenks of the Serrice for what ho has brought forward, and I 
Hope sincerels that some definite echeme, if not on the lines I bare proposed to this mecting, but sometling on that class of line, of teaching your men to be scamen first, and to spend some money on these cruizing ships, will be carricd out. Eren if they are eniling ships I do not care, but I think jou should teach your men to be seamen first, and then draft them iuto tho great battle-ships and cruizers and torpedo-boats afterwards. I think that rould be the best way of mecting the question, which to my mind is second to none in importance, as if we are to cxist as a nation me must kecp the command of the sea, eren though our Flet should hare to be double what it is at present.

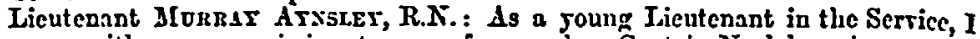
propose, with Jour permission, to say a few words. Captain Noel has giren a rery good résumé of tho ideal of a naral Officer, but I agree that the use of masts and Jards, his idcal, is unattainable. No doubt thero has been a strong fecling latels among the jounger branches of the Sertico against masts and jards, for where the guns and sards hare appeared together the guns hare always had to give way. The ship has to be made a perfect fghting machine, and it is no good putting up royal jards to play about, and all that sort of thing, if the guns are to be neglected. 'The ohip must be made a fighting slip, and the jards and masts only used as an auriliary for that purpose. Until that is thoroughly realized, the best thing will be to have the eails screred on to the yards, so that no one but a blocksmith could plas with them. It the present moment the men who ought to be learning how to fire a gun and use a rille are plajing about on the rojal jards. As regarls the Officers, the present sjstew of training, I think, is rery krong in many rajs. Licut. Clamberlain's Joung man, I think, has mostly his Captains to blame: I do not think it is possible that a midshipunn four jears at sea should not learn anything of his profcssion. I think the cadets froni the "Britannia" ought to go in a sea-going training ship for sis montls; the ship to te of the size of our smaller gunbonts, and to be worked cutirels bj the calcts. This scheme was tried on a larger scalc some sears since, but the large scale made it a failure. The cadet should be a short time in a large-nasted ship, and then for three jears in a corrette on a forcign station. After that time his serrice should be completed in a mastless ironclad. The present cxamination in ecamanship I can only characterizc as a farce; jou can toss up "IIcads I win, tails jou lose." If I get one Captain lue will gire me a first ; if I get another Captain he will pluck me. For this a pass examination in ecamanship sliould be substituted. Then on returning to England a Sub-Licutenant slould pass a pass esamination without a preparatory course in rarigation alone. They sliould then go through the gunnery, torpedo, and pilotage courses as at present. and then, optionally, a course at Greenwich. The prescnt mathematical course is simply an at temnt to put all the round men into square holes. Certain men nerer will learn mathematics, and you waste a great deal of a young Oficer's time by gending him there. I hare known one or two Officers who hare come away from there, and the only time they wanted to use their mathematics was to find how: much hannel was wanted to line a gun corer, and then they had to send out to some one to get him to do it for them. The extra course at Greenrich should last aboat three months, and tho examination should be about the present Beufort standanl. It would be onls the really first closs men, and of courso they would get a certin amount of kudos. 'Their promotion from Sub-Licutenant to Licutcuant for cs. amination is, I think, not at all right. Fou just miss a first class and get a sccond class instead: that means cighteen months time, which is hardly fair. As regards epccialists there, I think there is room for mans modifications. Jou do not want erers Gunners Licutenant to be up to $x$ and $y$ : what you want him to be able to do is to tc:Leh the mea under hin the use of tbeir reapons. If an Officer ristes to go in for a higher course of mathematics he ought to hare further time. dt presont tho course stops short just as jou are beginning to lcarn. The frst class people should hare a whole sear instead of nine monthe, and then go to Yortsmouth. Sir George Willes spoke about the cducation of seamen gunners, and about men not being allowed to go in for gunners owing to prerious wisconduct. I think that is rery wrong indecd. There were in my last ship in the Channel Squadron two or three men who were really a credit to the Serrice in crery way, and those men were not allowed to go in for seamen gunners simply because in their joung dags thes 
hed fair characters awarded them. As regards the training of stokers tho difficulty - to get men of sufficientls good physique; the sccond cluss stoker on entry is not a goct in that respect as he should be. The midshipman's education at sea I think ought to be in the hands of the Lieutenant and-not of the Naral Instruetor: I chink he would gire better all-round instruction. Of course in a sea-going ship there is no doubt the working of the ship ouglit to be the principal point, and all instruction should be subordinated to that. Signalmen I do not think you can posibls train bejond a certain extent. I signalman is born, not made-you can restly inprore them, but not make them. With regard to the results of the araining squadron serrice I nust Ens, from the men I hare secn coming out of it, they have not been so good as I could hare wished. The cause is that they are too worne, and the cruizes are not long enougb. The men deteriorate in physique, they are really orcrworked for young men between eighteen and twenty-one. They loo deteriorate in discipline. Too nme young men are shipped together without a sufficient learen of older hands, and the continual return to home ports may also be looked upon as a cause of this. When they como arsy thoj do not know very much sbout tbcir useful drills, theg affect to despise the humble seaman gunner, pretending that they are sailors:

Licutcnant LowRY : Haring carefully gone through the quarter bills of the ships in which I bare serred as Finst and Gunnery Lieutennnt during tho last seren and a half years, and taking gunnery instructors, torpedo instructors, captains of guns, and leading torpedo men, as specimens of highly-trained men in both branches, gunnery and torpedo, I find the following results: twenty-six were thoroughly efficient in their fghting and instruction dutics, and had receired a thorough ecaman's training in mested slips. One had ecrred in inastless ships only, and luckily was equally eff. cient. Threc captains of guns were poor scamen, and had rers little really seaman's training in ssiling ships, but they were good shots and were retained as captaius of the guns for that reason. 'They had the natural gift of being able to lay a gun. There was one torpedo instructor, and threo leading torpedo men, good, theoretical men, but who lost their heads and wero nearly useless in getting work done when in charge of a party of men. Thes had ecrred almost entirely in mastless ships, and had been quickly rated on azcount of their readiness and quickness as in. etructors, and instructors only. Sereral of the best practical acting senmen gunncrs, and one who ras acting captain of a gun for a considerable time, werc refused at the gunners slip on account of past conduct, or, in the case of the captain of a gun, because ho could not write a good hand, though he was an uncommonly good captain of a gun. Irobably the work to be done when a ship is aground is similar in some degree to much that will fall to our lot in a naval war, and tests what men are made of. Juring the meek of raried and incessant work in H.M.S. "Sultan" when on shore, whether it was in rigging purchases, dismounting and transporting guns, getting eails orer to stop the leaks, or placing and rigging a stcam pump, the men wlio came to the front and did their work thoroughly well were the men who were actire, well trained seamen aloft. It was not alwass the best scaman gunner, torpedo man, or marino artillery man who showed nost readincss of resource. Wholly agrecing, as I do, witl Captain Toel in his main contention that men sloould be thoroughly well trained in masted ships at sea first, there are some minor points in which $\mathrm{I}$ differ with him. If eass, "It is certainly neccsiars that a few eelect Lieutenants, who show great aptitude for scientific pursuits, should hare crery opportunity and cncouragement in becouning experts in their special lines," and I gather from the paragraph that, barring them, he proposes to do awas witl the funners, torpedo, and surresing lines. If so, tho Drill Book and figlting instruc. tions of the Serrices will bo largely in the hands of Officers with small experience at. sea, the rery result that the wholo puper so much deprecates. Fich branch of the work will, I beliere, be infinitely better dono bs those who make a special study of it than by an Oficer rho mas be watchkeping in a troopship, Gunnery Lieutenant of an ironclad, in a surresing schooner; or in charge of Whiteliead torpedocs alternately. Fex men can gire the necessars time to keep up thoroughly the knowiledge of all the minor details of each branch. We must rencenber, and no doubt we alwags do, that tho Serrice is far moro complicated now than it erer was bufore: there is far more to learn, and I do not think, with all duc respect to Lord

rOL. XXxIIr. 
Charles Beresford, that the ordinary executire Oficer in a ship can make limeclf thoroughly master of crerg detail in the non-exceutire branclies. I think he will do his work best by knowing suficiently about stcsm to eec that tho Chief Engineerdoes his duty, and then let him slone to do it. The result of laring the Channel Flect composed of masted and so less efficient ironclods is that in erery " of recent jears these ships nould hnre bad to bear the first onset had war brokcn out. Niotably this was the case in February, 18S8, when the Channel Filect of fire of our most ancient ironclads were hurried from Corsica to Genoa and Speria, and if certain thing 3 had happened which people talked about, thes wight haro had to ancet, burdened as they were with masts and sails, the French Toulon Flect.

Adminl WiLIEs: Throw them overboard.

Licutenant Lowre : I3ut that cannot be done till war is declared, and it was not dono till it might lare been too late. The order was giren to steam at full epeed from Corsica, and during that timo war might hare bcen declared, and our masts and sails would not hare been orerboard; morcorer, we should then haro to estemporise a very large number of fittings, such as iron-top screcne, to make these ships cficicnt. In conclusion, I would strongly urge that we make our Oflicers and men thorough sailors first, and then put them ALI through their courso of gunnery and torpedo, eclecting the best for scamen gunners, not only for instructors but for captains of guns, and for the moro important numbers at the gun. We ehould hare at least for heary guns two men at each gun, who aro thoroughly capablo of making a good shot, and not only the captain of the gun. I must differ with a prerious spenker about the results of the training squadron. I happened to be in a Channel Flect elip, where wo had a large number not only of joung seamen but of petty offecrs, and these men, who lad been brought up in the stirring work of a training squadron, were more efficient than the men thes replaced who had been brought up in Channel Squadron ships, they rspidly picked up their gunnery and torpedo work. Let the sailoring be done in largely increased training squadrons, and let our Channel and Forcign Flects be thoronghly scrriccable fighting sbips. On tho outbreal of war it might bo necesary, and most naral Officers think it nould bo necessary, if we hare an opportunity at any rate of maling a dash at the cnemy's flect whererer they wcre, whether ready or not, at sca or in harbour; and we might then be able to strike a deadly blow at their power, which no amount of training in the personnel and no perfection of material afterwards, would enable us to effect as cfliciently later on in the war. I am sure it would be the wish of erery naral Oflicer, soung or old, past or present, and whether serving in old or new tspe of ship, that he might bo in it on that occseion.

Captain Citanies Johssiose: So much of the ground taken up by our lecturer has been gone orer already, that it is rather diflicult to etrike out in a new line. I should first like to spcat on the question of masted ships and the Channel Squadron. I cennot belp thinking there is rather a pistaken idea in the Scrrico with regard to the adrocated usc of masts and sails. I think the two things sbould bo kent entirely spart, riz., masts and sails in tho Training Squadron, and masts and sails in the Channel Squadron, that is to say, in ironclads. I think crerybody will agrec that masts and sails in the Chanuel Squadron are uselcsa, and I beliere crersbods on board those shipg feels that they nro not thero for use; they look upon thein as oniy a way of nuling so much mork. Sail is made but stenm is not stopped; the engines aro kept going at the same time, and crerybody fecls that the suils are mere farce, they hare increly been set to giro the people somo excreise, and nobody bothers his head about trimming them, because they are not really being used; to brace the jards up night interfere with the routine, and therefore it is not done as it would male no difference to the ship. You set all sails in the "Minotaur," but. it does not make anj difference ono waj or tho other. I think all this gires a mistaken jdea, and I must say I wholly condemn the nests and eails in the Channel Squadron. Fot long ago the Admiral in command requestcd that tho atudding sails should be remored from ironclads. Studding eails no doubt arc uscless in an ironclad; the masts and sails are cqually uscless, and if one thing is remored why not the other? If the masts and eails are kept there for the purpose of grmnastics, or to teach men the use of the sails, why not retsin tho atudding sails as well as the sheet; but I must say I condemn them altogether. In tho Training Squadron it is another 
thing. We are accustomed to rely upon our sailo; we makc our passages under wil, and work our ships in and out of harbour; wo work our ships sometines in and ont of harbour in circumstances which would hare been conzidered worthy of notice oren in the dass of sailing ships. Our ships are long, undermasted, and, I won't ary unhands, but certainly slow in their morements, and it requires just as much judgment to handlo those ships as it crer did in the days of stiling ships. That being the croe, I think the exercise in tho Training Squalron under sail is perfectly filient. I know come distinguiehed Oficers, aud I might mention Sir Thomas Symonds, who are entircly againet hering sailing ships only as training ships, ther consider that all ships ought to hare steam powor, thereforo mucb cannot be said asinot our Training Squadron on account of its haring stesm powcr, but the sails at present arc perfectly eflicicnt. If those who object to masts and sails rould con. gider that it is not the same thing having them in a training squadron or the Channel Squadron, it mas perhaps clear up the difficulty. There is only one thing in Captsin Toel's paper with which I disagree, and that is when lie sajs that the prosent systcm of training young Officers is satisfactors. It is so, he says, if they are lept up to work at eea; but that is just what jou cannot do; when you hare a midehipman in the fore cabin at echool ho cennot be attending to any other work. $A$ boat midehipman is a boat midshipman by name, but ho cannot take tho interest in his boat that midshipmen formerly did. Formerly a midshipman mas always aw By in his bout; he was interested in his bont; ho was there to seo his bont hoisted up, and to ace tliat all was right about her. Now it is quito the contrary : a wid. sbipman does not care whether the boat is clean or dirt5, he takes no partieular intercst in her. I think it is rery objectionable, becauze it kills tho first buddings of $2 \mathrm{cal}$ in the young Officer. On the other hand, a higher standard of education, thet is to say, of theorctical education and book-lcarning, is necessary; a highel standard is now necessary than there mas formucrly. We cumnot go back to the old. fashioned way, where the youngsters in the Scrrice were required to learn the threc " $R$ 's," and nothing else; wo must hare a higher system, and to do that wo ouglit to clear the school work away entirels. The youngster should hare got through all pure achool work, that iz to say, puro mathematics and all thoso things; and he should hare got n thorough grounding in that before ho gocs to sca, and when ho goes to sea he should derote himself alcly to profeesional cubjects, that is to say, he should then begin the application of the things he had learnt before to his profession as a oeaman, that is to say, the trigononetry and tho different mathematics he had learot before should be applied to work out narigation and other problems of that nature. If that were tho caso we maj at once do away with the naral instruction. We hare plenty of Lieutenants in the Service who are quite capable of instructing roung Oflicers. It is an entirely different thing to what it was formerly, when Lieutennnts, as a rule, were uncducatcd, and certainly it was difficult to find an Officer who had a knowledge of mathematics. We haro plenty of Lientenants thoroughly well cdueated, and perfectls capable of taking chargo of midslipmen, in fact, I mas say much moro capable of taking the chargo and instruction of midslipmen than arerage naral instructors. One spealer mentioned that the Licutenant would also take charge of the other instruction of midshipmen. That I quite agree in; it would be an excellent plon; but there is another important adrantage, which is, that in tho grent outery against ciriliens on board ehips fou would remore the cirilians and increase the number of Licutenants; Jou would hare an additional Lieutenont in the ship; bo would be thero for the instruction of the midahipmen. Fou mould hare an additional fighting Onicer, so that you would bare positirely an additional Ijicutcnant in the Serrice without any additional expense. 'That is a matter rery well rorth attention. To do that we must cnter the midshipmen rather later. There are objections to that; I know that many object rery strongls to that, but I hope the objections will be orcreome. Wo know that distinguisbed Offecrs lave entered the Scrvice late; we know Lord Dundonald entered late, and therefore I think we must not suj a joungster cannot learn his work if be cuters later; besides, it is to bo remewbered there aro Oficers at tho present time in tho Serrico who entered at a later age. A distinguished Oncer entered at the ago of fifteen; the arerage ago is now fourteen. I think there were eome Officers who cntered at fifteen and a half, and some of those 3 ш 2 
Oficers lyold now distinguished positions in the Serricc. I think that is well wortl consideration, especially when we think that we should sweep aray the whole of the regular school instruetors, and should hare the widshipman absolutely free to do his duty withoul anj irterference on tho part of education. Ons more point, with regard to masted ships. I think crers eca Ofticer will agree that the onl thing to make seamen is to keep the ships at. sea. What we want is, that wo should be at ser; we ought to spend our time at sea, and ouglit not to be wrasting time in harbour, which is the rule of the Serrice now rather than the exception. Thio cxpensc of lecping ships at sea under stcam would alwajs militate against that; there would niwiss be an objection because of expense. If a large number of training ships, fully masted, were steam ships as wcll, you could keep them at sea under sail without cxpense, and that is a rers grcat argument indeed. I do not think ansthing could be gaid too strongly in farour of kecping our ships more at sea than they are at the present time.

Captain Loso, R.N.: After the very cloquent specelics we hare heard, I will not detain you one noment, but I should liko to teuder our thanks to Captain Nool for bringing this subject before us again so ably. There are one or two points on which I should like to remark. I cordially ngrce with all the speaters who hare put before sou that the first essential is that our Oficers and men should be ec:men, that is to eng, that they should hare their eca legs, and be just as much at bone at eca as on shore, and they certainly nerer will be unless they are kept at sea ut great deal more than they are at present. There was a curious instance the other day : a ship went round from Pembroke to Plymoutb, and crerybolly was sca-sick, I beliere, from top to bottom, senior Oflicer io junior stuker. In instance of the same kind oceurred to me wlien I was in command of the "A gamempon," when wo were going down Channel against a strong brecze, the stobers were all so sick that thes could not stoke. It therefore sccms that if you exerciso one-half of the Serrice without esereising the other half there will be difficulty. There is another point $I$ wish to bring before you. It seems to me a nistake that wo allow our young sea. men ir many cases to be detained in harbour sbips. I happen to know screral cases where young geamen under twenty-three years of age have been kept three sears in a slip like the "Nankin." It has been reported on by the Oficers, and erersbody deplored it; but surels a sssten under which such things can occur must be rers fault. It is because we hare not enough ships and a large enough training squadron; we ought to haro two or three such squadrons, and to make it an essential point to beep our Offiecrs and men at sea. Captain Noel speaks of the manourring ships under sail as the nearcst approach to what will occur in action. Tow I cannot ngree to that, because in my career, and specially when I serred under my friend, the gallunt Adeniral, Sir Georgo Willes, I liad the plensure of sceing a good deal of boat tactice under sail and steam, and the purt of ms experience which I think most raluable from the point of vicu of carrying a ship into action was that part in which we were doing naval tactics under steam, more cspecially at high specd.

- Captain NoeL : Jray I ask if that gives education to anybody besides the Officers actually carrying on the ship? When I say "taking a sinip into action," I refer to the whole crew.

Captain Iosa : Quite so. I was going to say, the manceurring of a ship could only cxercisg the man who is doing it, but if the crew and Ontecrs are at their quarters, and are pointing crery gun as they woukl be in action, I think they all gain a great deal of experience which can ouly be gained in that way. I think we to not do nearly enougl of tbat. It lias been adrocated by nany Officers ; I could mention Captain Fing with regard to torpedocs, and I think most of us who liare to do with torpedo-boats find we gain a great deal of expericnce from haring a number of resiels moring about; it was a point we had not previous csperience of, becauso the slow boats that me exerciscd with whenerer possible in the Navy de, not gire sou that experience that jou hare when you are going $18 \mathrm{knots}$. There is one point worth considcring in that matter, that the experience a man gets in a sailing ship is such a totally different tining from what he gets when stcaning at full speed in a molem steamer. The only experience that is raluable is what jou are going to lave in action; it is 110 good haring otbe: experience; you must 
cetualls point your gun when the siip is going at a high ratc of specd, and your stokers are strained to the utmost. I would remark aleo there is nothing said sbout training the scsmen as stokers, but something of that kind has been adrocated. I think the man who is in the stokehold rants nuch training as the man on the topesil yard. I would also urgo the grcat importsnce of tactics. Adwiral Baird apoke rery strongls last yea: on the importance of atudying tactics. I am afraid it io still the case that we hare no rcgular course of inetruction in what might be called strategJ and tactics; as part of our curriculum I am afraid it is still renting.

Admiral P. II. Cozors : I sloould like to add something to the last remark of Captain Long. The Gorernment hare made some adrance towards teaching otralegy and tactics at Green rich, of which they haro made me the humble instru. ment. A course of lectures on Naval Strategy and Tactics has been going on for three ycars there, and we are in tho middle of a courso now. A good deal has been aid about the dischargo of seamen as objectiouable. Sir Ceorge Willes knows rery well how often we hare talked orer the difficultice of that matter, but it is a matter chiefly in the hands of Captains of ships. If Captains of ships put men in a second claes and send them to receiving slips in the second class, there is a diff. culty in getting rid of them to sea, becauso you cannot send more than a certain proportion of them to any ship. 'Thees second-class men only grow worse and worse the longer they are lept in harbour, and ultimatcly, as far as my experience goos, it is from these men that the discharges chiefy come. It ras a matter forced on us ; it could not bo eraded. The remedy is, I think, for Captains to aroid putting men into the second class as far as possible. The lecturer suggeated that there were some speakers whó did not poesess eren a latent regard for scaunanship. I do not know whether ho was at all referring to some of $\mathrm{my}$ efforts in that direction, but I think there is not a single naral Offeer of the old school, that is, who hare served in seiling ships, who could possibly fail to arow the strongest latent regard for the old sesnuanship. But what $I$ am afraid of is that a grest many Oficers do not sufficiently suppreas that latent regard, that they allow their sentiment to a certain extent to orerride their judgwent. I ras strongly struck with that myself coming up Channel sa an umpirc in the "Rodncy" during the manceurres last jear. When stesming at good spced we paesed a most lorely ship, I thought one of the most lorely things I had ercr seen in my life, one of the great liners to Australia, under sail close hauled on the starboard tack, erergthing looking juot as it ought to look, erery sheet closo home, not a leach lifting, nothing wanting to please the ese and nuke one long that it might all come back again to the old life. But there we were standing in the "Rodney" beside the 67.ton gun, and what use was it? One could not help clinging to these regrcts, to these beautiful ideas, but we must simply sit upon them and stamp then down. Becausc, after all that has been said to-day, what it comes to is that our men hase to be trained, men and Officers, for that which they will hare to do when war breaks out. If you tell me the best prcparation for that is the training of the old school with masts and sailo, and if you prore it-and I muat be allowed to say that I think Licutenant Lowry has come nearest to proring it of anj of the speakers, because ho has actunlly brought the training of sailors into tho Gunnery bepartment, and he has shown as far 8 the figures go that these men turned out erceedingly good at their guns-if it be prored that tho men trained as royal yardsmen, and 80 on, wake the rery beet gunners, and that it is u neccesary point of gunnery and fighting training, all I can say is the sooner we set to and train them all in that was the better. But the proof io, I am sorry to saj, not suficient, and we hare to recollect what it comes to according to the lecturer's riews. He wants all our seamen to be kept for three jears of their twelre in sailing ships or maoted ahips. Thet means a nary by iteelf; it meane 7,000 men alwajs in masted ships? How unuch will jou lose if gou do that ? But still, if it is certain the training most and sail is a necessary beginning for the seaman of the present day, we inust hare it. Then I think we must go a otep further. Although it has been stated that a great authority, Admiral of the Fleet Sir Thomas Srmonle, wished that training shipe for sail crcreises should be steamers, I thisk if we are going to do the thing we had better do it thoroughly, and not hare steamers, but regular good thorough-going sailing resscls, and nothing 
clse. If jou are going to train the men and make them sailors of the old school, surelf ercry instant jou are under steam means so much loss to the scanzanship. But to me there is a bigger question behind the whole of this, that we must nod separate more than we can lelp tho two great Departments-what the lecturer calls the Exccutire Department and the Enginecring Department. There is no question that that rast separation at the present time is tho greatest difleulty that now crists, and if wo do not mind what we are about it is a growing difliculty which may orermaster us. For my part, although it is utopian to hopo for it, per hape, I think that our business is to uso crery ncrie and crers effort that it is possible to do to place the whole management of our ships in tho hands of a single class, to get the propulsion of the ship and the fighting of the ship into one sct of hands, and not into two. We are a rers long was off it now, but I am afraid tho more we lark back to the older style of things the more difficult it becomes to Iraw the two classcs tofether and to amalganste thean into one, and the more remote is the time placed at which that happy result miglit be arrived at. As to tho expense of lecping ships at sea under steam, I do not for ono monent believe it. I most fully ngree as to the ncecsity for keeping ships at eca. I think there is a great deal too much harbour, and with our scamen under our present sjstem the point is not so much whether they hare serred in masted or mastless ships, but rhether thes hare serred at ees at all. When I was Captain of the "Duko of Wellington" I made that one of my studics, and ras quite appalled to find what a rery small amounl of actual sog serrice most of our bluejackets liad had. As to remaining at sea, that is the great point. To be aray from lund, to be axay from bosts and going ashore, for people to bo thrown thoroughly into their ships and lept apart from ererything else. When I was in command of the "Thunderer," s mastless slip, in the Jeditcrrancan, I made it a practice to be ss much at sea as I could. We uscd not to steam so much, but our practice was to lic sometimes for a weck or ten dajs simply with fires banked. We used to enjoj it most thoroughly; so much was it enjojed that it became the practice of the fleet; and sereral times did the flect simply bank their fires up and lie at a good distance apart. You then had the opportunity of working up tle whole training of your ship free from inter. ruption, making erersbody accustomed to her, going on with your training rithout any irregularity or wish to get ashore, or any pressure of time for the Officer's baat, and so on, but you had all tho adrantage with but rers slight expense as to the espenditure of coal.

Admiral Sir J. C. D. IIAr : Jay I say one kord in corroboration of what fell from Adwiral Sir George Willes? The cridence of Captain Shaw was 60 clear and conclusire, I think, as to tho great lose of actirity in the scumen of the Nisy through want of training aloft, that I think the Report of the Committce before which he gave his eridence would be worth while any of my gallant friends here referring to. I happened to bo a mernber of the Parliamentary Coinmittee before which Captain Sliaw was examined, and he stated that he could no longer take men from the Niry for the work of the Fire 13rigade, but ho was obliged to get them from the merchant ships, hecsuse the old recklessness aloft, which was the best of all training for nerro and gallantry, lad cntirely gone aras from the Nary, and was only to be found in the sailing merchant ships. I recognize, of course, that our battle-ships cannot haro mats, but b5 some means or other thero should be a considerablo proportion of their early lives in which both seumen and Officers should liare that cecellent training which gires them the best possiblo nerro that men can lare.

Captain Nors, in repls: I nm much gratified witl the support I hare reccired to das. I think in the caec of almost erery speaker, cxecpt Adiniral Colomb, $I$ hare had upore or less support. I ouly wish a few more of the scamen I sce before me, who aro looked upon in tho Serrice as amongst the most reliable of our Officers, hed risen to make a fer remarks in farour of what wo must consider the backbono of our professional knowledge, that is "scamanship." Seamanship I know is looked upon by the younger Ofleers in a somewhat different light to what it was in former sears. I hold that scamanship is not necessarily tho porking of sails, but it is that knowledgo of a sea-going lifo which can only be gained bj constant sea-rork, and what I coutcad in ny paper is that we cannot get that constant sea-rork without 
patting our Oflicers and men into maeted ships. I think Admiral Colomb hes atber prored this for me. What ho told us is that lie uaed to take the "Thunderce" to at lot her lie like a log on the water, sometimes for a week together. I would ask that seamanship cxperience was gained by any man or Officer on board bs ouch a process? Why, cren the experience of boating that he learns in harbour is denicd him; be can, perhaps, do his gun-drill, his torpedo-drill, but what scamanship can ho learn? The lead cannot be hove to take soundings, and a man is not eren renuired to ateer, and Jct this is what is represented as scamanship training in licu of tho sailing of ships at ece. I am rery glad that wo harc had viers cxpressed by oome of the pounger Officers. I thinl Lieutenant Murray-Aynsley gare us a rery nice little speech stating what they think of tho matter, but I do not gatlucr from what he said that ho opposcs ecamanship. I dare say he would curtail the ocaman's troining rather more than is recommended in my paper. Lieutenant Lowry most thorouglily supports tho ricw of training men as sesnen, and I haso had support also, I am happy to sa5, from higher authoritics. Where my paper has been opposed more than in any other question is in tho matter of making tho Clanncl Squadron the squadron that rill carry on the seamanship training. I was in the Channel Squadron some years ago when Admiral Sir Qeofros $\mathbf{P}$. Hornby commanded it. In those days wo used to be under sail alono constantly; we would disconnect the ocrews, and tho equadron remained under sail for three or four dass at a time. I do not know why the same thing cannot happen uow: surely the samo shipe nre not more dangerous than they used to be. I purposely omitted, in the resscls I mentioned, some of those that caunot sail, the trin-serer ressels, for instance; but the "Minotaur," "IJercules," and "Triumph "classes are all fair sailers. I do not say thit thes should be taken in and out of port under sail, but still when they are at ecs there is no reason why they should not bo kept week after week under eail, and I belicre some of them would do as well as somo of the old linc-of-battle ships. It is generally admitted that mo ought to train our Offecrs and men to a sea life, and wo are told we can do it in tho ner ships, but inagine a squadron of "Mersess," or sone such new fast ressels, they carry very fer ecamen, and tho only order tho Oflicer of the watch has erer to giro is "Joatswain's mate, pipe a hand from cach part of the ship, up ashes." There is no ordering men about : there is no taxing the brains to know whether you are carrying on correctly in shifting jour topaail, of Eome other erolution which is such admirable practice for both Officer and man, and in place of mhich (in mastless ships) I do not knom wliat can be done. There ie, in my opinion, plenty of timo to train our Oflicers and men in the effective worling of the new battle-ships. I do not despair of this at all if they are first mado scamen, and thes would qualify after a scamanship training in a third of the time that would bo nccessary if brought up in ang other way. I am grateful to Lord Charles Beresford for his eupport : he has an independent voice with which at will he can gain the ear of the public, a powrer that alwajs carries great weight. I only hopo that ho will thoroughly support the training squadron, and get it doubled, if he can. Of course $I$ do not want masts and sails in battle-ships, but still if our Channcl Squadron was uscd as it has been up to the present with masts and eailsand there $I$ do not quite agree with Captain Jolustone, for I think thes might be worked more under sail as they used to be-I contend that they should and could carry on the training of the joungor Oficers and scamen : thes night bo periodically brouglst home and turned orer to the newer ships for sume cruizing in the summer; we should then get a rers fair amount of training in masted ships. I beg to express my most sincere thanks to $\mathrm{Sir}$ Henry Keppel for kindly taking the cliair. It is a circumstance on which I may most truly congratulato masclf that tho gallant Admiral, who for so many jears has been looked up to and estecmed as one of our most splendid scamen, should hare come amonget us in his old age and show that ho can still say a word for the old Serrice. I hare no doubt presently he will do so. I thank jou rery much for the patience with which jou hare listened to me, and I trust that this paper and tho discussion on it-mhich has been so well subtainedwill bear fruits to tho benefit of our Service.

Tho CaAinysx (Sir II. Keppel) : I do not knom, ladics and gentlemen, that $I$ am called upon to add anjthing on this occasion. I lare long been on tho Retired List, but I hare been resy much intercsted in all that has been said on both sides. 
I am only an old salt, and bare a rery strong fecling that the naral education, the sea-going education, was almajs necessary for our Scrrice. It is that that gircs tho sinew and strength to our men. I cloubt whether the oplendid men that now form the Nary would be the fine fellows thes are had they not gone through a sea training. Abore all they get that exercise of mind so neccesary for erery seaman that goes aloft. Ilis life is in his hands. It is not like the ecrgeant of marines who drills men. Tue man gocs aloft with his life in his hands, and he has to think before crersthing he docs, and I maintain that is the training that the men want. The old scliool has passed aray! I hare now only to thank you for jour kind attendance, and to say how much interested, one and all, we must hare been in the speches that hare been made to-daj, and in the lecture to which we have listened. 